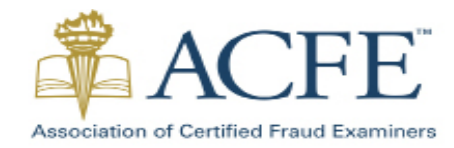

Indonesia Chapter \#111
Asia Pacific Fraud Journal

E-ISSN: 2502-695X, ISSN: 2502-8731

Volume 4, Nomor 2 (July-December) 2019

http://apfjournal.or.id/index.php/apf

\title{
ANALYSIS OF CORRUPTION IN REGIONAL GOVERNMENT IN 2016 RELATED TO THE REGIONAL GOVERNMENT BUDGET REALIZATION REPORT
}

\author{
$\bowtie$ Milda Aulia Eriyana \\ Indonesia
}

\author{
ARTICLE INFORMATION \\ Article History: \\ Received May 26, 2018 \\ Revised July 9, 2018 \\ Accepted January 11, 2019 \\ JEL Classifications: \\ D73; G18; H61 \\ DOI: \\ 10.21532/apfjournal.v4i2.116
}

\begin{abstract}
ABTRACT
Corruption can be caused by many factors. One of the factors in accounting reporting system is financial statement fraud. Since 2015, Indonesia has used an accrual basis of accounting in Operational Report, Balance Sheet, and Statement of Changes in Equity. In addition, Indonesia also uses cash basis of accounting in the Budget Realization Report (LRA), Report on changes in Accumulated Budget Surplus (LPSAL), and Cash Flow Report. The aim of this paper is to determine the components of Budget Realization Report (LRA) that can be utilized as a gap to commit corruption in the regional government in 2016. Budget Realization Report is a financial report relating to the budget allocation from the State Budget (revision) or Regional Budget (revision and the realization of budget allocation. The data in this paper are taken from the KPK's Performance Accountability Report 2016 based on the cases under investigation. The analytical methods use the related regulations, literature studies, and secondary data. The result of this studyshows that corruption in the regional government in 2016, related to the Budget Realization Report, occurred in the expenditure section butdid not occur in the revenue section. Corruption in the regional government was committed by Budget Users who got the highest budget in the region.
\end{abstract}

Keyword: Corruption, Budget Realization Report (LRA), Procurement of goods and services, Goods and Capital Expenditure, Budget Users

\section{INTRODUCTION}

In Indonesia, the use of state finances in regional governments is budgeted and implemented through the Draft of Regional Budget (Rancangan Anggaran Pendapatan dan Belanja Daerah / RAPBD). After joint discussions between the regional heads and the Regional House of Representatives, the Draft of Regional Budget becomes the Regional Budget

Corresponding author:

Address :-

Email : mildaeriyana134@gmail.com
(Anggaran Pendapatan dan Belanja Daerah / $A P B D)$. At the end of the year, the use of the budgets will be reported in the Regional Government Financial Report (Laporan Keuangan Pemerintah Daerah / LKPD).

In its implementation, the use of regional budgets is often utilized by some parties to obtain benefits for their own interest, or called fraud. In general, fraud is committed by making nonconformities Association of Certified Fraud Examiners (ACFE) Indonesia Chapter (C) 2019 
with what is supposed to be or a cheating process to get more profitable results. According to Michigan Criminal Law (in Yopi, 2012), fraud is a term that involves genes, including all the various meanings that can be used by human intelligence, which is carried out by an individual to get benefit from someone else with a wrong picture. Fraud is committed in various ways to satisfy human needs. Fraud can be committed by individual working alone to form fraudulent strategies or by a group of people so that the strategies can be covered up.

Most cases of fraud in Indonesia are related to corruption. Corruption is commonly known as one of the forms of fraud. Corruption, according to the Indonesian Encyclopedia (in Yopi, 2012), is a symptom in which the officials of government institutions abuse their authority and power by committing bribery, forgery, and other irregularities.

According to data from the Corruption Eradication Commission (Komisi Pemberantasan Korupsi / KPK), in 2016 there were 96 preliminary investigation cases and 140 full investigation cases consisting of 41 remaining cases in 2015 and 99 cases in 2016. Based on the figure, 48 corruption cases occurred in the regional government. The cases were committed by regional officials and regional civil servants. This indicates that there are still many corruption cases in the regional sector.

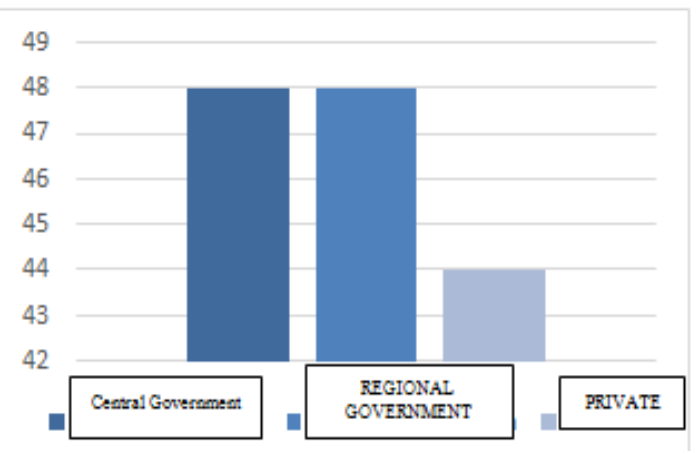

Figure 1 Corruption in 2016

Source: Processed from KPK from several studies (2016)

The implementation of regional financial budget is closely related to the Draft of Regional Budget (RAPBD). The Draft is then discussed by the regional head, such as the Governor, Mayor, or Regent, and the Regional House of Representatives. After the discussion, the Draft of Regional Budget (RAPBD) is then approved as the Regional Budget (APBD). At the end of the budget year, the realization and achievement of the implementation of the regional financial budget will be reported according to the economic, efficient and effective principles in the Budget Realization Report (Laporan Realisasi Anggran / LRA). The Budget Realization Report (LRA) in the Central and Regional Government Financial Reports, according to Government Regulation Number 71 of 2010, is recorded using cash-based budgets or recognizing the effect of other transactions and events when cash or cash equivalents are received or paid. When being paid for, the budget will be recorded as buying or expenditure in accordance with the standard account chart that has been determined as a deduction from the budget in the Budget Realization Report (LRA). Conversely, if there is an incoming revenue budget, it will be recorded as a budget increase in the Budget Realization Report (LRA). With the application of the cash-based budget in the Budget Realization Report (LRA), the budget that has actually been used or the budget that is still entitled to be obtained are not visible, because the recording in the Budget Realization Report (LRA) is limited to the budget in and out only. Therefore, this allows corruption to occur through fraudulent actions in the LRA. Based on the description above, the researcher is interested to conduct a research entitled "Analysis of Corruption in Regional Government in 2016 Related to the Regional Government Budget Realization Report".

\section{Formulation of the Problem}

1. What components in the Budget Realization Report (LRA) were used as a gap to commit corruption in the 
regional government in 2016 ?

2. How could the components in the Budget Realization Report (LRA) be a gap to commit corruption in the regional government in 2016 ?

\section{Objectives of the Study}

1. To find out the components in the Budget Realization Report (LRA) which were used as a gap to commit corruption in the regional government in 2016

2. 2. To find out the position in the regional government regarding corruption in the Budget Realization Report (LRA) in the regional government in 2016

\section{THEORETICAL BASIS \\ Corruption}

Corruption, according to Law Number 31 of 1999 in conjunction with Law Number 20 of 2001, includes:

1. Unlawful acts for the purpose of enriching oneself, other people / entities that are detrimental to the state finances / economy (article 2).

2. Misuse of authority over positions held that could be detrimental to the state finances / economy (article 3).

3. Bribery (Articles 5, 6, and 11).

4. Embezzlement in office (Articles 8, 9, and 10).

5. Extortion in office (Article 12).

6. Related to chartering (Article 7).

7. Gratuity (Articles 12B and 12C).

According to Erry Riyana Hardjapamekas (2008), the high number of corruption cases in this country is caused by several factors, such as lack of role model and leadership of the national elite, low salaries of Civil Servants, weak commitment and consistency in law and regulation enforcement, low integrity and professionalism, weak internal control mechanisms in all banking, financial, and bureaucratic institutions, condition of the work environment, condition of job duties, condition of community environment, and the weakness of faith, honesty, shame, morality and ethics.

According to the KPK (in the Ministry of Education and Culture; 2011), there are
2 factors that cause corruption: internal factors and external factors. Internal factors are the driving factors for corruption, including aspects of individual and social behavior and. The aspect of individual behavior includes greed, lack of morality, and consumptive lifestyle. External factors are triggers of corrupt behavior caused by outside factors. External factors include aspects of people's attitudes towards corruption, economic aspects, political aspects, and organizational aspects.

The legal basis of corruption is Law Number 31 of 1999 concerning Eradication of Corruption Crime (State Gazette of the Republic of Indonesia Number 140 of 1999, Supplement to State Gazette of the Republic of Indonesia No 3874) which amended Law Number 3 of 1971, Law Number 20 of 2001 concerning Amendment to Law Number 31 of 1999 on Eradication of Corruption Crime (State Gazette of the Republic of Indonesia Number 134 of 2001, Supplement to State Gazette of the Republic of Indonesia Number 4150), TAP MPR Number XI / MPR / 1998 concerning the Implementation of Clean Country which is free from corruption, collusion, and nepotism, and Presidential Instruction No. 11 of 2005 concerning the Coordination Team for the Eradication of Corruption Crimes.

\section{Regional Government Financial Statements (Laporan Keuangan Pemerintah Daerah/LKPD) \\ Legal Basis of Regional Government Financial Statements (LKPD)}

1. The 1945 Constitution of the Republic of Indonesia, especially in the section governing State finance article 23, paragraph 1: "The state budget as a manifestation of state financial management is set every year by law and carried out openly and is responsible for the prosperity of the people."

2. Law Number 17 of 2003 concerning State Finance;

3. Law Number 1 of 2003 concerning State Treasury; 
4. Government Regulation Number 71 of 2010 concerning Government Accounting Standards;

5. Government Regulation Number 24 of 2005 concerning Government Accounting Standards;

6. Government Regulation Number 58 of 2005 concerning Management of Regional Finance;

7. Law Number 23 of 2014 concerning Regional Government;

8. Minister of Home Affairs Regulation Number 64 of 2013 concerning Application of Accrual-Based Government Accounting Standards to Regional Governments;

9. TechnicalBulletinNumber3concerning Presentation of Regional Government Financial Reports in accordance with Government Accounting Standards with Conversions;

10. Minister of Home Affairs Regulation Number 13 of 2006 concerning Guidelines for Regional Financial Management.

\section{Accounting Record Basis for Local Government Financial Statements (LKPD)}

Both the central and regional governments in Indonesia have 3 basis of accounting: cash basis, cash toward accrual (CTA) basis, and accrual basis. Cash basis of accounting is a basis of accounting basis that recognizes the effect of transactions and other events when cash or cash equivalents are received or paid. An accrual basis is an accounting basis that recognizes the effect of transactions and other events when the transaction and event occur, without regard to when cash or cash equivalents are paid. Cash towards accrual (CTA) basis is a basis of accounting developed by the Government Accounting Standards (SAP) Committee in accordance with Government Regulation Number 24 of 2005 and Government Regulation Number 71 of 2010 which was implemented from 2005 to 2014. According to Minister of Home Affairs Regulation Number 64 of 2013, the local government applied accrual-based Government Accounting Standards at the latest in the 2015 budget year. However, in addition to the Minister of Home Affairs Regulation, there was a regional head regulation governing the regional government accounting policies set no later than 31 May 2014. However, according to Government Regulation Number 71 of 2010, cash basis is used to recognize revenue, expenditure, transfer, and financing. Meanwhile, accrual basis is used to recognize assets, liabilities, and fund equity.

\section{Regional Government Accounting System (SAPD)}

Regional Government Accounting System (SAPD) includes accounting procedures and techniques ranging from identification of transactions, recording in journals, posting to ledgers, preparation of trial balance, and presentation of financial statements. Regional government financial statements present budget realization report, report on changes to accumulated budget surplus, balance sheets, operational reports, cash flow statements, changes in equity reports, and notes to financial statements.

\section{Components of Budget Realization Report (LRA)}

1. The Budget Realization Report (LRA) presents an overview of sources, allocations, and use of economic resources managed by the central / regional government, which illustrates the comparison between the budget and its realization in one reporting period. The components of the Budget Realization Report (LRA) are the budget and the realization of income, expenditure, transfers, financing, and receipts.

2. LRA income is income receipt by the State General Treasurer / Regional General Treasurer or by other government entities that increases the accumulated budget surplus in the period of the relevant fiscal year which is the government's right, and does not need to be repaid by the government. 
3. Expenditure is all spending by the State General Treasurer / Regional General Treasurer that reduce the accumulated budget surplus in the period of the relevant budget year which will not be repaid by the government.

4. Transfer is the receipt or expenditure of money by a reporting entity from / to other reporting entities, including balance funds and revenue sharing funds

5. Financing is any income / expenditure that does not affect the net worth of the entity that needs to be repaid and / or will be received again, both in the relevant fiscal year and the following fiscal years which are mainly intended to cover the deficit or take advantage of the budget surplus. Funding receipts can be derived from loans and divestment proceeds. Financing expenditures are, among others, used for repayment of loan principal, lending to other entities, and equity participation by the government.

\section{Regional Government}

According to Law Number 23 of 2014 Article 57, the administrators of the provincial and regency / city governments consist of the Regional Heads and Regional House of Representatives assisted by the Regional Apparatus. In Article 209 article 1 , the provincial apparatus consists of the Regional Secretariat, the Secretariat of Regional House of Representatives, Inspectorate, Department and Agency. Whereas, according to article 209 paragraph 2 , the regency / city apparatus consists of the Regional Secretariat, Secretariat of the House of Representatives, Inspectorate, Department, Agency, and Sub-District.

\section{METHOD}

Type of Research and Description of Research Object

This study uses a quantitative and qualitative method because it contains numbers accompanied by an analysis of a rule, theory, and related data to find the results of the study. The purpose of the study is to find out corruption in the regional government in 2016 related to the Budget Realization Report which its recording uses a cash-based approach and to find out the position of local government administrators who commit corruption in the regions.

\section{Data Collection Technique}

According to Sugiyono (in Umar Basri, 2017), the data sources used in the study are primary data and secondary data. Primary data are obtained from investigation cases on KPK's Accountability Report (LAKIP KPK) in 2016, while secondary data are obtained from related regulations, literature studies, and information media. Primary data are cases of investigations in 2016 and 2015 which are still ongoing.

\section{RESEARCH RESULTS AND DISCUSSION}

From the KPK data found kin the background above, therewere 44 corruption cases in the regions. The corruption cases were committed by regional government officials including the Governor, members of the Regional House of Representatives, Regent, Mayor, Section Head, Subdivision Head, Head of Secretariat, Regional Secretary, and several regional civil servants. Of the 44 corruption cases in the regional government, 24 corruption cases were related to regional budget, 12 cases were related to the Draft of Regional Budget (revision) and Regional Budget (revision), and 12 other cases were related to the Regional Government Financial Statements. Corruption cases in the Draft of Regional Budget (revision) and Regional Budget (revision) were cases related to the process of budget formulation and revision in regional budgets. Corruption cases in the Local Government Financial Statements were related to the realization of the budget that had been implemented. Regional Government Financial Statements consist of Budget Realization Reports, Operational Reports, Balance Sheets, Changes to Equity Report, Report on the revision of Accumulated Budget Surpus, and Notes of Financial Statements (Catatan atas Laporan Keuangan / CALK). 
However, this study focused only on the Budget Realization Report because it was recorded using a cash-based approach.

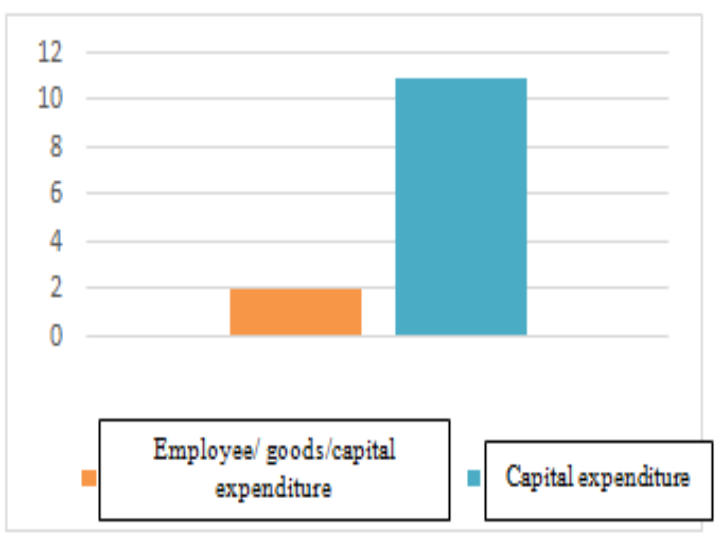

Figure 2 Corruption Cases in Regional Government in 2016 related to the Budget Realization Report

Source: Processed from KPK from Various Studies (2016)

The components of the Budget Realization Report (LRA) that were affected by corruption cases in the regional governmentin2016weregoodsexpenditure (6 cases) and capital expenditure (6 cases). Goods expenditure and capital expenditure are very closely related to the process of procurement of goods and services because the two expenditures constitute operational expenditure related to the implementation of activities and infrastructure development in a region. The value composition of goods expenditure in the Regonal Budget structure of March 2016 was $21 \%$ of the total expenditure, while the capital expenditure was $23 \%$ of the total expenditure. Goods expenditure and capital expenditure were carried out with a direct expenditure mechanism, which means that budgeted expenditure was directly related to the implementation of programs and activities.

In the implementation, both goods expenditure and capital expenditure use the process of procurement of goods and services. However, there are differences in the procurement of goods and services which cand be categorized as goods expenditure and capital expenditure. Goods expenditure is budget expenditure for the purchase of consumable goods and / or services. Goods expenditure consists of expenditure for operational and non-operational goods, service expenditure, maintenance expenditure, travel expenditure, Public Service Agency (BLU) expenditure, and expenditure on goods to be handed over to the public / regional government. Capital expenditure is budget expenditure to obtain or add value to fixed assets / other assets that benefit more in one accounting period and exceed the minimum capitalization of fixed assets or other assets determined by the government. Minimum capitalization value for asset value was IDR 750,000.

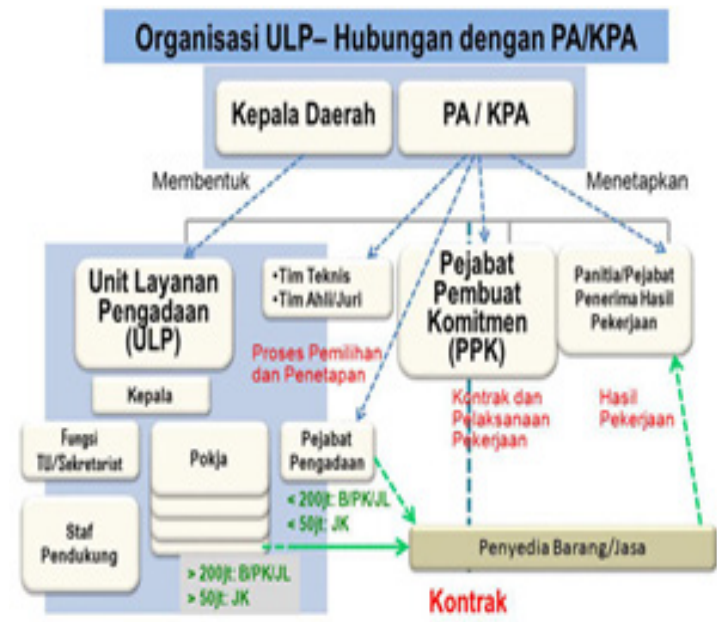

Figure 3

The Relationship between the

Procurement Service Unit (ULP) and Budget User / Proxy of Budget User (PA/ KPA)

In its implementation, goods expenditure and capital expenditure in the process of procurement of goods and services in 2016 were related to Presidential Regulation Number 4 of 2015 concerning the fourth amendment to Presidential Regulation Number 54 of 2010 concerning the procurement of goods / services of the Government. In accordance with Figure 2, positions in the Procurement of Goods or Services are Budget Users (PA), Proxy of Budget Users (KPA), Commitment 
Makers (PPK), Procurement Service Units (ULP), Procurement Officials, Committee / Officials Receiving the Work Results , Government Internal Auditor (APIP), Providers of Goods / Services, Consulting Services, and other related services. Procurement of Goods or Services (PBJ) can be done through goods / services providers and self-management. Providers of goods / services are business entities or individuals that provide goods / construction work / consulting services / other services. Procurement of goods and services which is carried out through Goods / Services Providers consists of PA / KPA, PPK, ULP / Procurement Officials, and Committee / Officials Receiving Work Results. Self-management procurement is work that is planned, carried out, and / or supervised by itself, and those in charge of the budget are other government agencies and / or community groups. The procurement of goods and services which is carried out through self-management consists of PA / KPA, PPK, and the Committee / Officials Receiving the work results.

The process of procurement of goods and services starts from planning by PA / KPA to fulfill and achieve regional goals in accordance with the regional Budget Execution Document (DIPA) and the budget in the Regional Budget. PA / KPA establish PPK in the process of implementing procurement of goods and services. PPK then carries out its main tasks and authorities including establishing implementation plans for procurement of goods and services, issuing documents related to procurement of goods and services, signing contracts, implementing contracts, controlling and reporting on the implementation of contracts, and submitting work results of the contracts to PA / KPA. In implementing procurement of goods and services, there will be two choices, through self-management and through provider. If the procurement of goods and services is implemented through self-management, it is carried out independently. However, if the procurement of goods and services is implemented through provider, the selection of providers is conducted through auction, selection, competition, contest, or direct election / appointment / procurement.

In the process of procurement of goods and services, many parties are involved in implementing a project. Inevitably, fraud cases such as corruption will be committed by some people in carrying out the projects. Cases of corruption in projects are usually due to the position / authority in an organization.

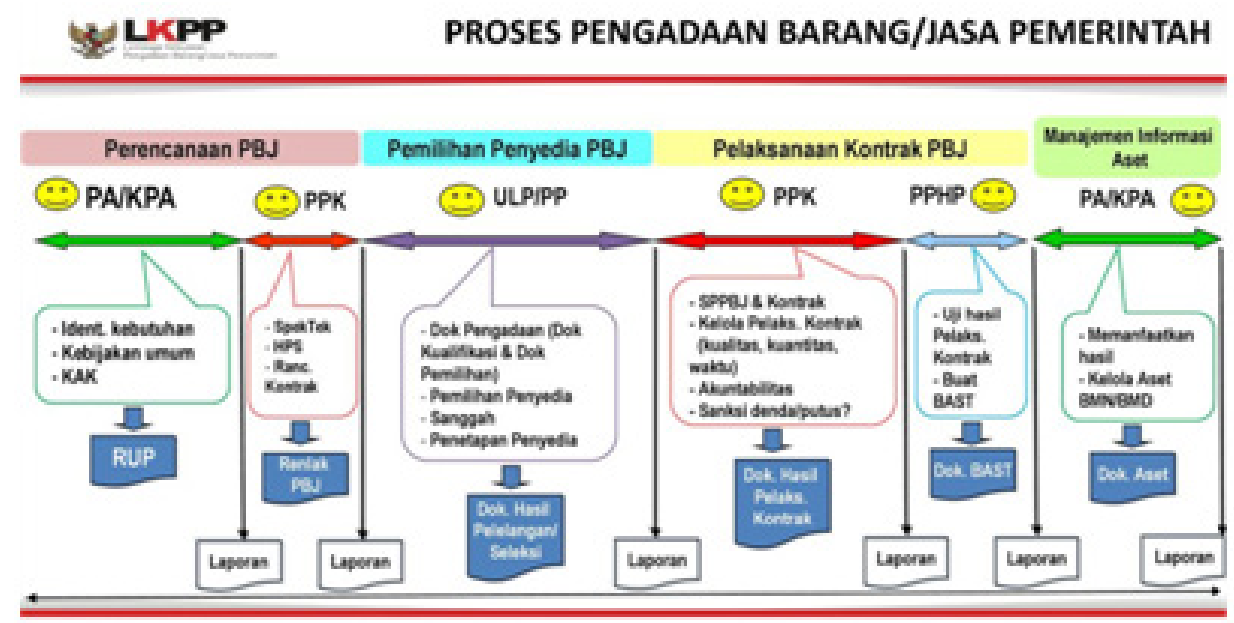

Figure 4

Government Goods / Services Procurement Process 


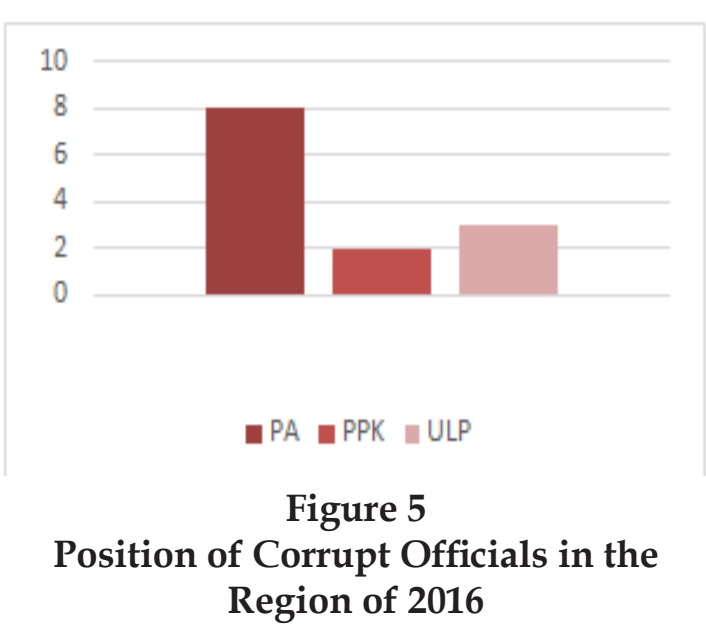

From the KPK's Accountability Report data 2016, 13 cases of corruption in the regions related to the Regional Government Financial Statements (LKPD) were mostly committed by Budget Users (PA), such as the regional heads in cities, regencies, and provinces, involving 8 people. Some cases of corruption in the regions, related the Regional Government Financial Statements (LKPD), were committed by the Commitment Makers, involving 2 people. While cases of corruption in the regions related to the Regional Government Financial Statements (LKPD) were committed by the Procurement Service Unit (ULP) / workgroup, involving 3 people. The corruption cases were generally committed due to conflict of interest, mark up of project prices, personal interests, and group interests.

Regarding fraud in the financial statements, there were several corruption cases in the regions related to spending accounts on the Budget Realization Report (LRA), such as:

\section{Falsification of Procurement of Goods and Services (PBJ) Documents}

This is very possible because the office holders know the loopholes to cheat or commit fraud through documents by making fictitious documents. Document falsification usually occurs because the relevant officials have an interest for themselves and for a group so that the budget that should be maximized for the procurement of goods and services will be misled and fooled by falsifying documents as if they were real.

1. Budget realization that is not in accordance with output and outcome

The realization of the expenditure budget is realized well in a numerical manner but it turns out that it is not fully allocated for procurement of goods and services. So far, in the Budget Realization Report, the shopping accounts in regions just reached above $50 \%$ or below $100 \%$. This was due to the large expenditure budgeted. Although the budget has not been fully implemented, in many regions in Indonesia this budget has been misused for the benefit of an individual. As a result, the realization of the budget can be said to be good in a report but it cannot be said good in output and outcome.

\section{Continuous transactions}

Most of these cases occur in capital expenditure. On an accrual basis, capital expenditure is recorded as an asset for certain purposes, such as for infrastructure development. For the ongoing development, on an accrual basis, it will be recorded as the ongoing construction (KDP) which is carried out on a contract basis for a certain period of time. However, some cases of ongoing construction have stopped on the way. As a result, the cash register on the capital expenditure is recorded that the contract is already running and the budget has been issued for the value of the contract, even though the output and outcome of the ongoing construction still cannot be utilized by the community in accordance with the objectives of the region.

From the accounting perspective, because Indonesia applies accrual basis and cash basis, financial statement fraud can affect not only the Budget Realization Report but also other financial statements. This study focuses from the perspective of Budget Realization Report because the budget realization will affect budgeting in the Budget Execution Document for the following year which will then affect the budget in the Draft of Regional Budget 
(RAPBD) and Regional Budget (APBD).

\section{CONCLUSION}

From the results of the analysis it can be concluded that corruption in the regional government in 2016 affected the components of Budget Realization Report (LRA) in the expenditure section related to the procurement of goods and services, namely goods expenditure and capital expenditure. Corruption in the regional government in 2016 was mostly committed by Budget Users (PA) as the highest budget holders in the regional government. Corruption in the regionalgovernment was caused by various factors, such as conflict of interest, mark up of project prices, personal interests, and interests of a group. Corruption in the Budget Realization Report (LRA) was related to fraud in financial statements, such as document falsification, budget ralization that was not in accordance with outputs and outcomes, and ongoing transactions.

\section{Suggestion}

To minimize fraud in financial statements, especially in the Budget Realization Report (LRA), it is recommended to improve internal control toward officials and the implementation of regional budgets. In this case, the internal control is conducted by regional government internal auditors, such as the Financial and Development Supervisory Board (BPKP) and the Regional Inspectorate.

To improve the effectiveness of the regulatory system, it is recommended to make provisions related to the budget execution contained in the regulation in order to make the execution more adequate. Conflict of interest between regional government officials and related parties regarding the use of regional budgets can be minimized through applications completed with barcodes so that the use of regional budgets can be controlled properly.

In addition, the expenditure budget and other financing expenditures that have been issued as well as the income, transfers, and receipt of financing that have not been received must be clearly recorded in the notes to the financial statements (CALK) to facilitate disclosure. The budget in the Budget Execution Document for the following years needs to be reviewed, especially related to the realization of expenditure and revenue existing in the Budget Realization Report (LRA). It is also necessary to hold a training and selection on the anti-corruption work culture so as to create conducive environment and provide good welfare to the community. Finally, the regional objectives can be achieved.

\section{REFERENCES}

Republik Indonesia. 2014. Undang-undang Republik Indonesia Nomor 23 Tahun 2014 Tentang Pemerintahan Daerah. Jakarta:Sekretariat Negara.

RepublikIndonesia. 2001. Undang-Undang

Republik Indonesia Nomor 20

Tahun 2001 Tentang Perubahan atas Undang-undang Nomor 31 Tahun 1999 Tentang Pemberantasan Tindak Pidana Korupsi. Jakarta:Sekretariat Negara.

Republik Indonesia. 2013. Peraturan Menteri Dalam Negeri Nomor 64 Tahun 2013 tentang Penerapan Standar Akuntansi Pemerintahan Berbasis Akrual pada Pemerintah Daerah. Jakarta:Sekretariat Negara.

Republik Indonesia. 2010. PP Nomor 71 Tahun 2010 tentang Standar Akuntansi Pemerintahan. Jakarta:Sekretariat Negara.

Republik Indonesia. 2010. Lampiran II.01 PP 71 Tahun 2010 Standar Akuntansi Pemerintah Berbasis Kas menuju akrual. Jakarta:Sekretariat Negara.

Republik Indonesia. 2010. Lampiran I PP 71 Tahun 2010 Standar Akuntansi Pemerintah Berbasis Akrual.2010. Jakarta:Sekretariat Negara. 
Republik Indonesia. 2014. Peraturan Menteri Keuangan Republik Indonesia Nomor 270/PMK.05/2014 Tentang Penerapan Standar Akuntansi Pemerintahan Berbasis Akrual pada Pemerintah Pusat. Jakarta:Sekretariat Negara.

Republik Indonesia. 2010. Peraturan Presiden Republik Indonesia Nomor 54 Tahun 2010 Tentang Pengadaan Barang/Jasa Pemerintah. Jakarta:Sekretariat Negara.

ACCH. Fahri Nurmallo. https://acch.kpk. go.id/id/jejak-kasus/374-fahrinurmallodiakses tanggal 22 Mei 2018.

AmanatPenderitaan Rakyat. 2016. Reportasi dan Legalitas Antirasua KPK Saat Ini Dipertaruhkan Folitik Transaksional, Balter Selalu Ditudingkan. https:// www.facebook.com/permalink. php?story_fbid $=356491894739751 \&$ id $=219388391783436$ diakses tanggal 22 Mei 2018.

Amalo, Dis. 2017. Kasus PLS NTT Segera Dilimpahkan ke Pengadilan Tipikor. http:/ / sinarharapan.net/2017/01/ kasus-pls-ntt-segera-dilimpahkanke-pengadilan-tipikor/diakses tanggal 24 Mei 2018.

Association of Certified Fraud Examiners. 2011. Fraud-Related Internal Controls. Texas:ACFE Inc.

BAB II LANDASAN TEORI. http:/ / digilib. unila.ac.id/13542/17/BAB\%20II. pdfdiakses tanggal 22 Mei 2018.

Direktorat Jenderal Pendidikan Tinggi. 2011. Pendidikan Anti Korupsi untuk Perguruan Tinggi. Jakarta:Kemendikbud.

Fadhil, Haris. 2017. Dipindah ke Bandung, 2 Tersangka suap Walkot CImahi Segera Disidang. https://news.detik. com/berita/3409580/dipindah-kebandung-2-tersangka-suap-walkotcimahi-segera-disidangdiakses tanggal 22 Mei 2018.
Hendrawan, Parliza. 2017. Kasus Suap, Bupati Banyuasin Yan Anton dituntut 8 Tahun Penjara.https://nasional. tempo.co/read/857657/kasussuap-bupati-banyuasin-yan-antondituntut-8-tahun-penjaradiakses tanggal 22 Mei 2018.

Hermawan, Fajar W. 2016. Korupsi dan Gratifikasi yang menyeret Bupati Nganjuk. https://beritagar.id/ artikel/berita/korupsi-dangratifikasi-yang-menyeret-bupatinganjukdiakses tanggal 22 Mei 2018.

Images $\quad 1 . \quad$ http://images1. proka l.co/we bbalpos / files/berita/2016/07/15/ kurniaverifikasi-telah-sesuaiperpres.jpgdiakses tanggal 28 Mei 2018.

Kandi, Rosmiyati Dewi. 2016. Jalan Panjang Kasus Korupsi Pasar Besar Madiun. https:/ / www.cnnindonesia.com/ asional/20161022171535-12-167225/ jalan-panjang-kasus-korupsi-pasarbesar-madiundiakses tanggal $22 \mathrm{Mei}$ 2018.

Komisi Pemberantasan Korupsi. 2016. Laporan Akuntabilitas Kinerja 2016 Merangkai Integrasi Menjaga Sinergi. Jakarta:KPK.

Komite Standar Akuntansi Pemerintahan. 2006. Buletin Teknis Penyajian Laporan Keuangan Pemerintah Daerah Sesuai dengan SAP dengan Konversi. Jakarta:Komite Standar Akuntansi Pemerintahan.

Lembaga Kebijakan Pengadaan Barang/ Jasa Pemerintah. Pengadaan Barang/ Jasa Pemerintah. http://slideplayer. info/slide/11820267/65/images/2/ ROSES+PENGADAAN+BARANG/ JASA+PEMERINTAH.jpgdiakses tanggal 28 Mei 2018. 
Mahdi, Hendri. 2015. Tata Cara Pengadaan Barang Metode Pengadaan Langsung (PL) .https://www.kompasiana. com/tenderwatch/tata-carapengadaan-barang-metodepengadaan-langsung-pl_552839ca6 ea83458058b4582diakses tanggal 22 Mei 2018.

Maskur, Fatkhul. 2016. Belanja Modal Daerah 2016: Pagu Rp199 Triliun, Realisasi Kuartal I $R p \quad 1$ Triliun. http: / / finansial.bisnis.com / $\mathrm{read} / 20160425 / 10 / 541162 /$ belanjamodal-daerah-2016pagu-rp199. triliun-realisasi-kuartal-i-baru-rp1triliundiakses tanggal 22 Mei 2018.

Natalia, Desca Lidya. 2014. Atut dan Wawan Jadi Tersangka Korupsi Alkes Banten. https://www.antaranews. com/berita/412939/atut-danwawan-jadi-tersangka-korupsialkes-bantendiakses tanggal $24 \mathrm{Mei}$ 2018.

Patiro, Yopi Morya Immanuel. 2012. Diskresi Pejabat Publik dan Tindak Pidana Korupsi. Bandung:Keni Media.

Prlm. 2014.Atut dan Wawan Ditetapkan Sebagai Tersangka Dalam Kasus Alkes Banten. http:// w w w.pikiran-rakyat.com / nasional/2014/01/07/265181/atutdan-wawan-ditetapkan-sebagaitersangka-dalam-kasus-alkesbantendiakses tanggal 24 Mei 2018.

Putra, Lutfy Mairizal.2016. KPK PeriksaWali Kota Madiun sebagai Tersangka Kasus Dugaan Korupsi Pembangunan Pasar Besar. https://nasional.kompas. com/read/2016/11/08/11425971/ kpk.periksa.wali.kota.madiun. sebagai.tersangka.kasus.dugaan. korupsi.pembangunan.pasar.besar. diakses tanggal 22 Mei 2018.
Rastika, Icha. 2014. KPK Awasi Penanganan Kasus Korupsi Pendidikan Rp 77 Miliar di NTT. https://regional.kompas. $\mathrm{com} / \mathrm{read} / 2014 / 06 / 30 / 1301441 /$ KPK.Awasi.Penanganan.Kasus. Korupsi.Pendidikan.Rp.77.Miliar. di.NTTdiakses tanggal 22 Mei 2018.

Tunggal, Iman Sjahputra dan Amin Widjaja Tunggal. 2000. Audit Kecurangan dan Akuntansi Forensik. Jakarta:Harvarindo.

Triwib. 2009. Pengendalian Intern Atas Pengelolaan Aset Negara. https:// www.djkn.kemenkeu.go.id/2016/ artikel/baca/2320/PengendalianIntern-Atas-Pengelolaan-AsetNegara.htmldiakses tanggal 22 Mei 2018.

Wisnu. 2015. Kasus Tukar Guling Tanah Pemkot Tegal Segera di Sidang. http:/ / www.aktual.com/kasus-tukarguling-tanah-pemkot-tegal-segeradi-sidang/diakses tanggal $22 \mathrm{Mei}$ 2018.

Yudiono, OS. 2013. II. TINJAUAN PUSTAKA. http://digilib.unila. ac.id/525/7/BAB\%20II.pdf diakses tanggal 22 Mei 2018. 